\title{
Correlation between androgen receptor expression and FGF8 mRNA levels in patients with prostate cancer and benign prostatic hypertrophy
}

\author{
Q Wang, G W H Stamp, S Powell, P Abel, M Laniado, C Mahony, E-N Lalani, J Waxman
}

Department of
Histopathology,
Imperial College
School of Medicine,
Hammersmith
Campus,
Du Cane Road,
London W12 ONN, UK
Q Wang
G W H Stamp
S Powell
E-N Lalani

Department of Surgery, Imperial College School of Medicine,

Hammersmith

Campus

P Abel

M Laniado

Department of Oncology, Imperial College School of Medicine,

Hammersmith

Campus

J Waxman

Laboratory of Viral

Carcinogenesis, Imperial Cancer Research Fund,

Lincoln's Inns' Fields, London WC2, UK

C Mahony

Correspondence to: Dr Jonathan Waxman.

Accepted for publication 29 July 1998

\begin{abstract}
Aim-To investigate the correlation between androgen receptor expression and fibroblast growth factor 8 (FGF8) mRNA levels.

Methods-39 human prostate cancers and 14 benign prostatic hypertrophy specimens were examined immunohistochemically for androgen receptor expression and by in situ hybridisation and reverse transcription polymerase chain reaction for FGF8 expression

Results-In 39 tumours there was a statistically significant negative correlation between tumour grade and FGF8 expression and a positive correlation between FGF8 and androgen receptor expression. All 14 benign hypertrophy specimens expressed moderate to high levels of FGF8 and androgen receptor.
\end{abstract}

Conclusions-Loss of FGF8 may be a factor involved in the development of prostatic cancer.

(F Clin Pathol 1999;52:29-34)

Keywords: fibroblast growth factor 8; in situ hybridisation; androgen receptor; immunohistochemistry

Prostate cancer is the second most common cause of male cancer deaths in the Western world. Currently 13300 men each year develop prostate cancer and 8800 die in England and Wales. ${ }^{12}$ The majority of patients with prostate cancer respond to androgen withdrawal treatment by medical orchiectomy or with antiandrogens. This effect is transient, and eventually the majority of prostate tumours become androgen independent. ${ }^{3}$

It is possible that growth factors or cytokines may contribute to the development of androgen independence, and the stromal fibroblast proliferation that is a feature of this cancer. Fibroblast growth factors (FGF) are multifunctional, heparin binding polypeptides which share structural similarity. Ten members of this family have currently been identified. ${ }^{4}$ Signalling is mediated by a group of transmembrane tyrosine kinase receptors, known as the fibroblast growth factor receptors (FGFR) 1-4, which show structural and functional diversity. ${ }^{5}$ Fibroblast growth factors and their receptors are involved in the process of development, wound healing, angiogenesis, and tumorigenesis. ${ }^{67}$

FGF8 is also known as androgen induced growth factor (AIGF), and is of potential interest in prostatic neoplasms. In an initial observa- tion Leung et al have shown a positive relation between FGF8 mRNA expression and tumour grade in patients with prostatic cancer. ${ }^{8}$ FGF8 was initially isolated from the conditioned medium of androgen dependent mouse mammary cancer cell line SC-3 after testosterone stimulation. ${ }^{9}$ The human FGF8 gene is located on chromosome $10 \mathrm{q} 25-26^{10}$ and the nucleotide sequences are highly conserved. ${ }^{11}$ Alternate splicing of the first exon of the FGF8 gene generates four different transcripts and results in four protein isoforms that differ at the amino terminus. ${ }^{12}$ However, the biological significance of the multiple FGF8 protein isoforms is unknown.

The murine homologue has $100 \%$ homology at the protein level with human FGF8, and the gene is detectable in the testes and ovaries of the adult mouse. ${ }^{13}$ In humans, FGF8 expression is confined to testis, prostate, and kidney. ${ }^{14}$ FGF8 is transcriptionally activated by the mouse mammary tumour virus, suggesting that the gene may be a proto-oncogene. ${ }^{915}$ This view is supported by the observation that FGF8 can transform NIH3T3 cells ${ }^{16}$ and that FGF8 and the mouse mammary tumour virus MMTV lead to tumour formation in Wnt-1 mice. ${ }^{13}$

Overexpression of fibroblast growth factors or members of the FGFR family has been observed in many different carcinomas ${ }^{17-19}$ and may have an important role in hormone dependent malignancies. FGF2/bFGF functions as a growth factor in the benign and malignant prostate. ${ }^{20}{ }^{21} \mathrm{FGF}-7$, which is also known as keratinocyte growth factor (KGF), is involved in paracrine interactions between mesenchyme and epithelium in normal and malignant prostate. ${ }^{22} 23$

In prostate cancer, FGF8 expression is detectable in the androgen responsive cell line $\mathrm{LNCaP}$ and the unresponsive cell lines PC-3, DU145, and ALVA-31. ${ }^{11}{ }^{14}$ Recombinant FGF8 stimulates the growth of LNCaP but not PC-3. ${ }^{11}$ Three human FGF8 gene isoforms-FGF8a, FGF8b, and FGF8e- have been isolated from the DU145 cell line ${ }^{14}$ and transformation of NIH3T3 cells by these three isoforms leads to tumour formation in nude mice. ${ }^{14}$

The primary aim of this study was to determine whether there was a statistically significant relation between FGF8 mRNA and androgen receptor protein expression in patients with prostate cancer or benign hypertrophy, as might be expected from the in vitro data. We have investigated FGF8 gene expression in benign and malignant prostate by in situ hybridisation and reverse transcription 


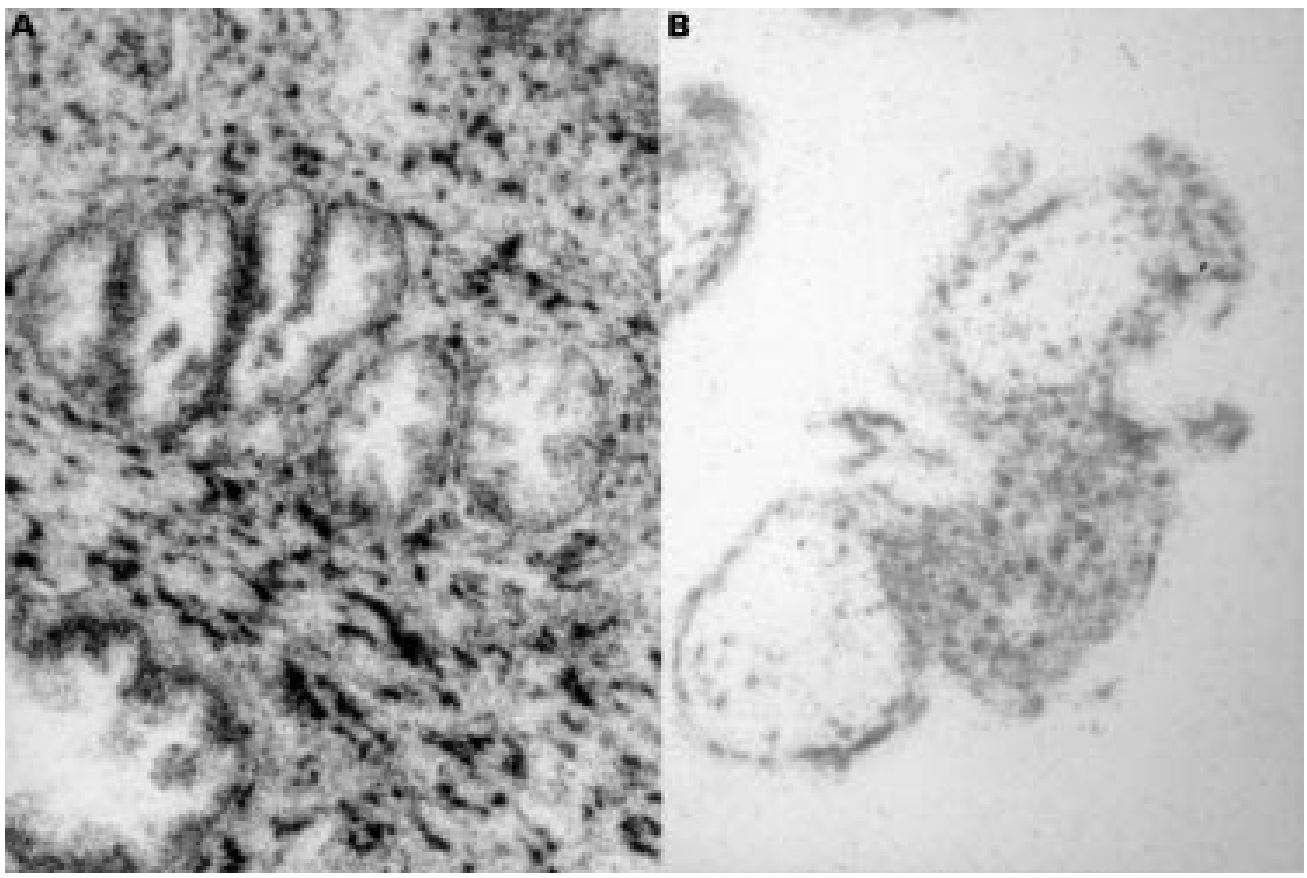

Figure 1 (A) Very strong hybridisation of $\beta$ actin $m R N A$ in both epithelial and stromal cells serving as a positive control. (B) Placental tissue a positive control for FGF8 mRNA showing labelling of the trophoblastic cells.

polymerase chain reaction (RT-PCR), and compared gene expression with androgen receptor expression determined by immunohistochemistry, because of the potential relevance of FGF8 to prostate cancer progression. FGF8 mRNA was expressed in all 14 benign prostatic hypertrophy specimens that we examined. In 39 tumours there was a negative correlation between tumour grade and FGF8 expression and a positive correlation between FGF8 and androgen receptor expression.

\section{Methods}

SAMPLES

All chemicals were purchased from Sigma unless otherwise stated.

Benign and malignant prostate samples from untreated patients, obtained by transurethral resection between 1990 and 1996, were

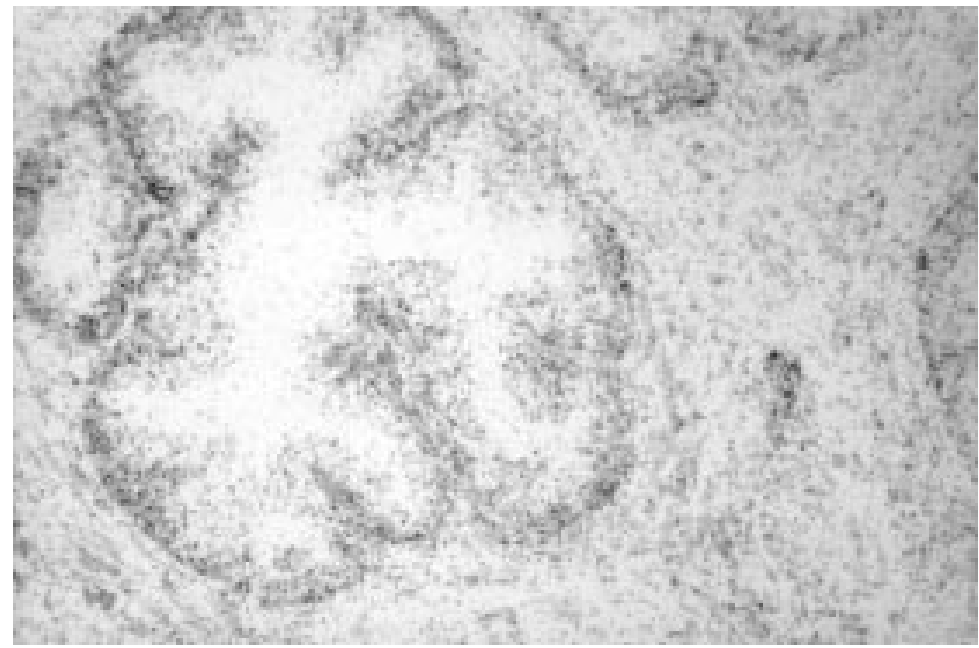

Figure 2 A benign gland in nodular hyperplasia showing uniform, relatively even grain distribution of labelled FGF8 (++) over the epithelial cells, with sparse hybridisation to stromal fibroblasts. A corresponding section hybridised with the sense probe was negative. routinely processed, formalin fixed, paraffin embedded, and subsequently retrieved from the Hammersmith and Ealing hospitals surgical archives. Serial sections (5 $\mu \mathrm{m}$ thickness) from 53 samples from 14 patients with benign prostatic hyperplasia and from 39 patients with prostate cancer were cut and processed for in situ hybridisation, immunohistochemistry, and histological assessment using the Gleason grading system. ${ }^{24}$ Full term placental tissue was used as the positive control.

IN SITU HYBRIDISATION

FGF8 cDNA was isolated by RT-PCR from an ovarian carcinoma cell line. The PCR product of this reaction was shot gun cloned into the pCR3 vector (Invitrogen). The insert fragment was $714 \mathrm{bp}$ from position 1 to 714 of the FGF8 cDNA sequence, ${ }^{11}$ corresponding to the FGFa isoform. ${ }^{12}$ Antisense and sense riboprobes were generated using SP6 and T7 RNA polymerases, respectively. A $1 \mathrm{~kb} \beta$ actin antisense riboprobe was used as a positive control for the detection of hybridisable mRNA in tissues, as described previously. ${ }^{25}$

Riboprobes labelled with $\alpha^{35} S$ were synthesised from cDNA cloned in vectors, using RNA polymerases $^{26} ; 0.5-1.0 \mu \mathrm{g}$ of linearised template were incubated with $2.5 \mu \mathrm{l}$ of $5 \times$ transcription buffer, 2 units of RNAsin (Promega), $5.6 \mathrm{mM}$ of dithiothreitol (DTT), $1.0 \mathrm{mM}$ each of ATP, guanosine triphosphate (GTP), and cytosine triphosphate (CTP), 14.0 $\mu \mathrm{M}$ of ${ }^{35} \mathrm{~S}$-uridine triphosphate (Amersham International), and 5 units of RNA polymerase (Promega), made up to a total volume of 12.5 $\mu \mathrm{l}$ for one hour at $37^{\circ} \mathrm{C}$. The template was then destroyed by adding $1 \mu \mathrm{l}$ of DNAse (Promega) at $37^{\circ} \mathrm{C}$ for 15 minutes. The reactions were diluted with $25 \mu \mathrm{l}$ of $10 \mathrm{mM}$ DTT and $1.5 \mu \mathrm{l}$ of ribosomal RNA (10 mg/ml) (Boehringer Man- 


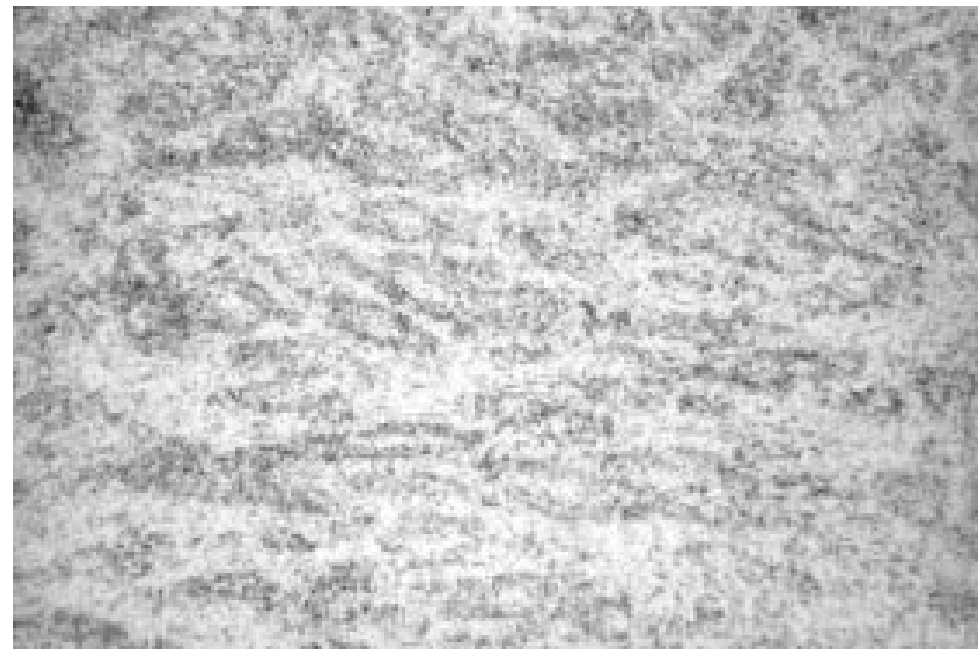

Figure 3 A low power view reveals high levels of FGF8 labelling (+++) on the epithelial cells of a Gleason grade 3 carcinoma.

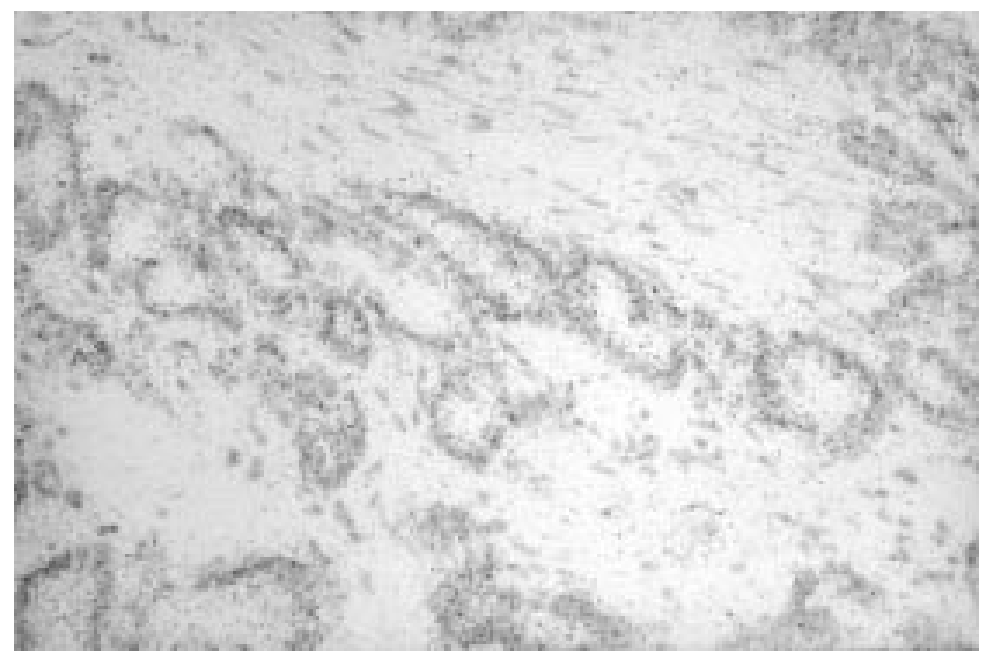

Figure 5 The same tumour shown in fig 3 has strong nuclear AR immunoreactivity in tumour cells, with slightly weaker expression in benign epithelial cells, but not basal cells.

Table 1 Correlation between Gleason grade and FGF8 gene expression in benign and malignant prostate tissue

\begin{tabular}{llllll}
\hline \multirow{5}{*}{ Gleason grade } & \multicolumn{3}{l}{ Gene expression } & \\
\cline { 2 - 5 } & - & + & ++ & +++ & Total \\
\hline BPH & 0 & 0 & 6 & 8 & 14 \\
G2 & 1 & 1 & 0 & 3 & 5 \\
G3 & 1 & 1 & 7 & 7 & 16 \\
G4 & 2 & 4 & 6 & 1 & 13 \\
G5 & 1 & 3 & 1 & 0 & 5 \\
p $=0.02$ & & & & & \\
\hline
\end{tabular}

$\mathrm{BPH}$, benign prostatic hypertrophy.

nheim). Unincorporated nucleotides were removed by centrifugation in a Chromaspin-30 column (Clontech) and the integrity of the probes was confirmed by gel electrophoresis.

Sections were deparaffinised in xylene under RNAse limited conditions, soaked in phosphate buffered saline (PBS), $\mathrm{pH} 7.2-7.4$, and then subjected to proteinase $\mathrm{K}$ treatment $(20$ $\mathrm{mg} / \mathrm{ml}$ ) in PBS for 10 minutes at $37^{\circ} \mathrm{C}$. Sections were fixed in $4 \%$ paraformaldehyde for 20 minutes and then treated with $0.25 \%$ acetic anhydride in $0.1 \mathrm{M}$ triethanolamine for 10 minutes, hybridised with $\alpha^{35} \mathrm{~S}$ labelled ribo- probe $\left(1 \times 10^{6} \mathrm{cpm} / \mathrm{section}\right)$, and incubated at $55^{\circ} \mathrm{C}$ overnight. After hybridisation, the sections were washed for 60 minutes in $50 \%$ formamide buffer $(50 \%$ formamide, $300 \mathrm{mM}$ $\mathrm{NaCl}, 10 \mathrm{mM} \mathrm{Na} \mathrm{HPO}_{4}, 10 \mathrm{mM}$ Tris/HCl, 50 $\mathrm{mM}$ EDTA) at $55^{\circ} \mathrm{C}$ three times and then washed in TNE buffer $(0.1 \mathrm{M} \mathrm{NaCl}, 10 \mathrm{mM}$ Tris, $1 \mathrm{mM}$ EDTA) at $37^{\circ} \mathrm{C}$ for five minutes. The sections were then treated with RNAse A $(100 \mathrm{mg} / \mathrm{ml})$ at $37^{\circ} \mathrm{C}$ for one hour, washed twice in $2 \times \mathrm{SSC}(\mathrm{NaCl} /$ sodium citrate $)$ at $65^{\circ} \mathrm{C}$ for one hour, and then in $0.5 \times$ SCC for a further 30 minutes.

Autoradiography was carried out by dipping the sections in $\mathrm{K} 5$ emulsion (Ilford), exposing them for 10 to 20 days at $4^{\circ} \mathrm{C}$ and developed in D19 (Kodak). They were counterstained with haematoxylin. All sections were initially assessed by the same observer who was blind of androgen receptor status.

RT-PCR

Ten benign prostatic hyperplasia specimens and four tumours were examined to confirm the expression of FGF8 mRNA using RT-PCR. Frozen samples were homogenised and total RNA was extracted using the RNAzol ${ }^{\mathrm{TM}}$ method (Biogenesis). RNA pellets were washed with $70 \%$ ethanol and dissolved in water.

cDNA was synthesised using Moloney murine leukaemia virus (MMLV) reverse transcriptase (Gibco). Two micrograms of RNA were incubated with $0.5 \mu \mathrm{g}$ of oligo (dT) 12-18 primer in a total volume of $10 \mu \mathrm{l}$ at $70^{\circ} \mathrm{C}$ for 15 minutes. The samples were then placed on ice and 200 units of mouse MMLV reverse transcriptase were added, together with a 1/5 volume of $5 \times$ reverse transcriptase buffer, 40 units of RNAse inhibitor, and $0.5 \mathrm{mM}$ of dATP, dCTP, dGTP, and dTTP (Promega) to give a final volume of $20 \mu \mathrm{l}$. The mixture was then reverse transcribed at $42^{\circ} \mathrm{C}$ for one hour, after which one tenth of each transcription reaction was amplified in $50 \mu \mathrm{l}$ solutions including $1 \times$ Taq DNA polymerase buffer (Promega), $2.5 \mathrm{mM}$ of $\mathrm{MgCl}_{2}, 0.5 \mathrm{mM}$ of dNTPs, 2.5 units of Taq DNA polymerase, and $100 \mathrm{ng}$ each of primers RB376 (5'AAAGGCAAGGACTGCGTCTTCACG3') and RB359 (5'CGTGAAGGGCGGGTAGTTG AG3'). ${ }^{14}$ PCR was then carried out at $94^{\circ} \mathrm{C}$ for one minute, $68^{\circ} \mathrm{C}$ for 50 seconds, and $72^{\circ} \mathrm{C}$ for 1.5 minutes for a total of 35 cycles. The PCR product was analysed on $1.5 \%$ agarose gel. GAPDH gene was used as the positive control and amplified using B504 primer (5'GCCACATCGCTCAGACACCA3') and B505 primer (5'GATGACCCTTTTGGCTCCC C 3 '), ${ }^{27}$ under PCR conditions: $95^{\circ} \mathrm{C}$ for five minutes, then 30 cycles of $94^{\circ} \mathrm{C}$ for one minute, $65^{\circ} \mathrm{C}$ for one minute, and $72^{\circ} \mathrm{C}$ for three minutes.

\section{IMMUNOHISTOCHEMISTRY}

Sections were dewaxed, rehydrated, and then treated in a microwave oven at 700 watts in $0.01 \mathrm{M}$ trisodium citrate, $\mathrm{pH}$ 6.0, for five minutes. ${ }^{28}$ The sections were then blocked with $3 \%$ bovine serum albumin (BSA) in PBS for 60 minutes, treated with mouse antiandrogen 


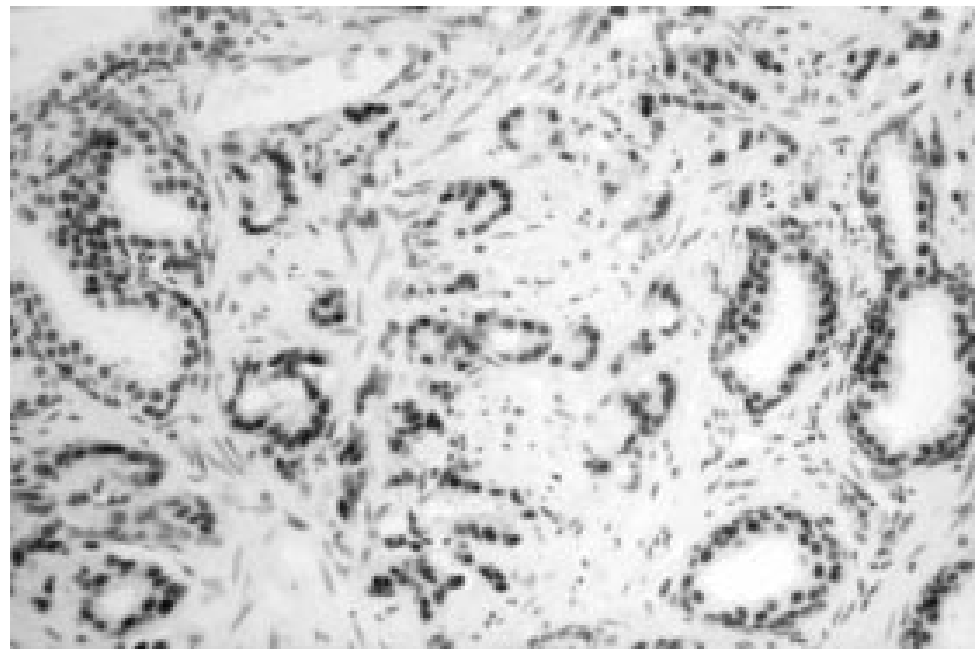

Figure 4 Weak (+) labelling of a Gleason grade 4 prostatic carcinoma for FGF8 ${ }^{35}$ S-labelled ribroprobe with autoradiography.

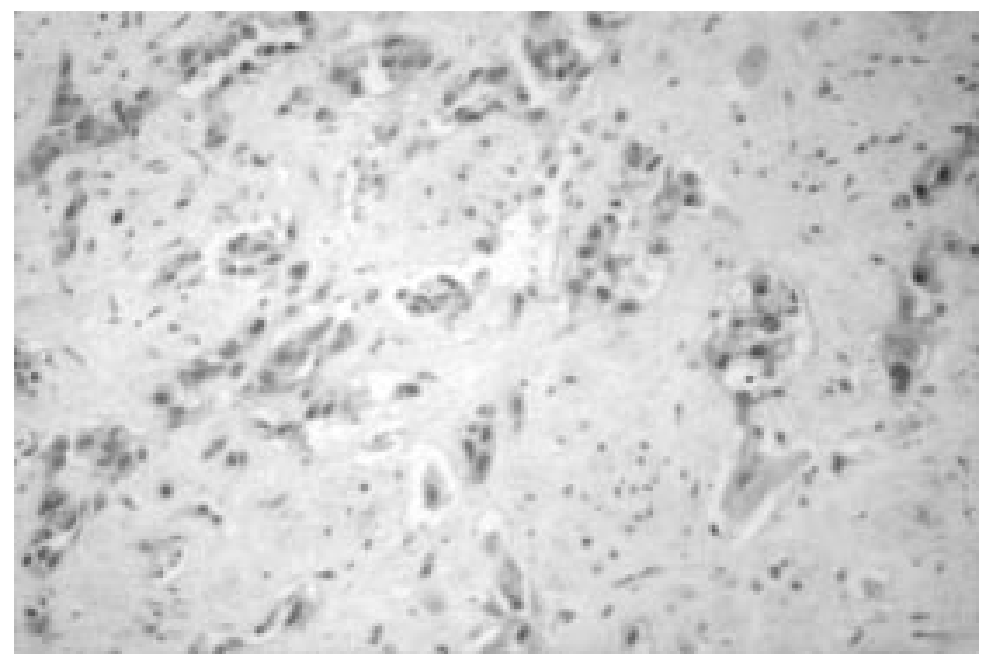

Figure 6 Immunostaining showed weak and heterogeneous reactivity for androgen receptor in the same tumour shown in fig 5.

Table 2 Correlation between Gleason grade and androgen receptor expression in benign and malignant prostate tissue

\begin{tabular}{lllll}
\hline & \multicolumn{3}{l}{ Androgen receptor expression } & \\
\cline { 2 - 4 } Gleason grade & + & ++ & +++ & Total \\
\hline BPH & 2 & 11 & 1 & 14 \\
G2 & 1 & 3 & 1 & 5 \\
G3 & 1 & 11 & 4 & 16 \\
G4 & 7 & 5 & 1 & 13 \\
G5 & 5 & 0 & 0 & 5 \\
p $=0.003$ & & & & \\
\hline
\end{tabular}

$\mathrm{BPH}$, benign prostatic hypertrophy.

receptor antibody (1:100; Biogenex), and incubated overnight. Sections were biotinylated with rabbit antimouse immunoglobulin (Dako) for 60 minutes and peroxidase conjugated with streptavidin $(1: 200)$ for a further 60 minutes. This was followed by an additional two washes for five minutes in PBS. Enzyme activity was developed with $1 \mathrm{mg} / \mathrm{ml} \mathrm{3.3'-}$ diaminobenzidine tetrahydrochloride (DAB) and counterstained with haematoxylin.

\section{STATISTICS}

The $\chi^{2}$ test was used to calculate the correlation between FGF8 mRNA expression and Gleason grade, androgen receptor expression and Gleason grade, and FGF8 mRNA expression and androgen receptor immunohistochemistry.

\section{Results}

FGF8 RNA EXPRESSION BY IN SITU HYBRIDISATION In situ hybridisation was evaluated according to the percentage of cells labelled and the degree of labelling, where \pm indicated equivocal labelling of 50-100 grains/cell, + indicated weak labelling equivalent to $100-200$ grains/ cell, ++ moderate labelling of $200-500$ grains/ cell, and +++ strong labelling of more than 500 grains/cell. ${ }^{29}$ All samples expressed +++ for $\beta$ actin, showing that RNA was well preserved (fig 1A).

Placental trophoblasts were used as a positive control for FGF8 labelling (fig 1B). FGF8 labelling in epithelial cells in benign prostatic hyperplasia was uniformly distributed (fig 2). Stromal expression of FGF8 labelling was observed in some desmoplastic stromal fibroblasts, and was most prominent in hyperplastic stromal nodules. Six of the 14 benign prostatic hyperplasia specimens showed ++ labelling and eight of 14 showed +++ labelling.

FGF8 labelling was examined in 39 prostatic cancers (figs 3 and 4). There were no Gleason grade (GG) 1 tumours. One of five GG2 tumours did not express FGF8, one showed + labelling and three +++ labelling. One of 16 GG3 tumours showed no labelling, one + labelling, seven ++ labelling, and seven +++ labelling. Two of 13 GG4 tumours showed no labelling, four + labelling, six ++ labelling, and one +++ labelling. One of five GG5 tumours showed no labelling of FGF8, three + labelling, and one ++ labelling. Statistical analysis showed a negative correlation between Gleason grade and FGF8 gene labelling in prostatic tumours ( $p=0.02$; table 1 ) which was maximal in the moderately differentiated tumours and significantly lower in the high grade tumours.

ANDROGEN RECEPTOR EXPRESSION

All samples expressed androgen receptor to variable degrees (figs 5 and 6). Two of 14 benign prostatic hyperplasia specimens had + staining intensity, $11++$, and one +++ . One of five GG2 tumours showed + staining intensity, three ++ , and one +++ . One of 16 GG3 tumours showed + staining intensity, $11++$, and four +++ . Seven of 13 GG4 tumours showed + staining intensity, five ++ , and one +++ . Five GG5 tumours expressed a low level of androgen receptor which was often heterogeneous. There was a significant negative correlation between Gleason grade and androgen receptor expression ( $\mathrm{p}=0.003$; table 2$)$.

CORRELATION BETWEEN FGF8 MRNA EXPRESSION AND ANDROGEN RECEPTOR EXPRESSION IN PROSTATE TUMOURS

FGF8 mRNA labelling and androgen receptor immunostaining intensity was compared in the 39 tumours. The five FGF8 mRNA negative samples all showed androgen receptor + staining intensity. Five of nine + FGF8 staining samples had + androgen receptor staining and four showed ++ androgen receptor staining. 
Table 3 Correlation between FGF8 gene and androgen receptor expression in malignant prostate tissue

\begin{tabular}{llllll}
\hline & \multicolumn{2}{l}{ FGF8 } & & \\
\cline { 2 - 5 } Androgen receptor & - & + & ++ & +++ & Total \\
\hline+ & 5 & 5 & 4 & 0 & 14 \\
++ & 0 & 4 & 10 & 5 & 19 \\
+++ & 0 & 0 & 0 & 6 & 6 \\
Total & 5 & 9 & 14 & 11 & 39 \\
$\mathrm{p}<0.001$ & & & & & \\
\hline
\end{tabular}

Four of $14++$ FGF8 expressing tumours showed +androgen receptor labelling, and 10 ++ labelling. Five of $11 \mathrm{FGF} 8+++$ tumours exhibited ++ androgen receptor labelling, and six +++ labelling. There was a strong positive correlation between androgen receptor staining intensity and FGF8 expression ( $p<0.001$; table 3).

FGF8 MRNA EXPRESSION BY RT-PCR

Primers B405 and B406 generated a GAPDH gene PCR product on all tested samples. For FGF8 RT-PCR, primers RB376 and RB359 generated a fragment of $244 \mathrm{bp}$ from exon 3 . All 10 benign prostatic hyperplasia specimens and four tumours showed a 244 bp product by PCR (fig 7).

\section{Discussion}

We have investigated FGF8 mRNA expression by in situ hybridisation and androgen receptor expression by immunohistochemistry in malignant and benign prostatic hyperplasia specimens. FGF8 mRNA was detected in 14 benign prostatic hyperplasia specimens in a relatively uniform fashion. There were moderate or high levels of hybridisation on epithelial as compared with stromal cells, apart from hyperplastic stromal nodules. In malignant prostatic epithelium the greatest hybridisation was seen in moderate or well differentiated carcinomas and considerably less in poorly differentiated carcinomas.

All samples expressed androgen receptor to a variable degree in epithelial cells. The majority of benign prostatic hyperplasia specimens showed uniform, moderate degrees of androgen receptor expression. Most (67\%) poorly differentiated carcinomas (GG4 and GG5) showed low androgen receptor immunoreactivity which was often heterogeneous, while the majority $(\sim 90 \%)$ of low grade carcinomas showed moderate to high immunoreactiviy.

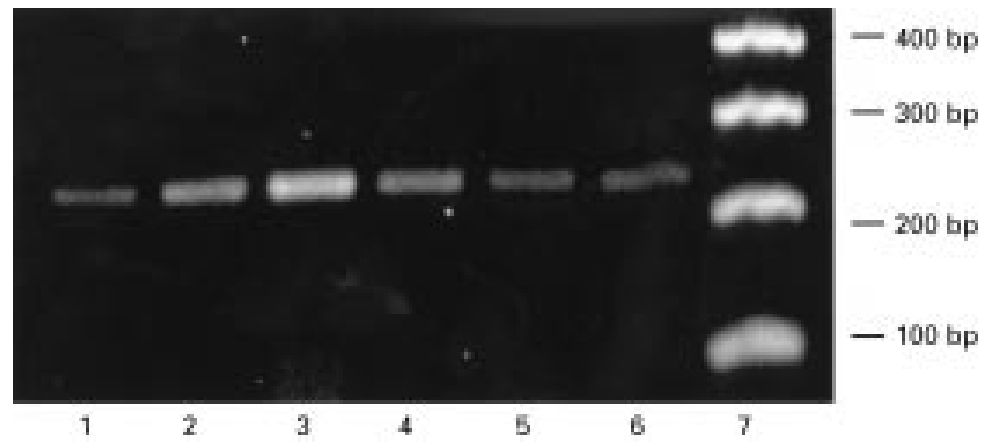

Figure $7 \quad$ FGF8 gene expression by reverse transcription polymerase chain reaction (PCR). Lanes 1-4: BPH; lanes 5-6: prostate cancers; lane 7: molecular weight. All specimens have a 244 bp PCR product.
There was a significant positive correlation between the levels of androgen receptor expression and FGF8 mRNA in malignant prostatic epithelial cells. Stromal expression of androgen receptor corresponded to weak but definite FGF8 hybridisation in benign stromal nodules.

Our results are not in agreement with previously published in situ hybridisation data. ${ }^{8}$ Using a digoxigenin labelling antisense riboprobe in 31 prostate cancers, Leung et al reported that the highest levels of FGF8 expression were seen in poorly differentiated tumour cells: in five benign prostatic hyperplasia cases there was no FGF8 expression in either epithelial or stromal cells, while some "benign" basal cells in the epithelium adjacent to tumour expressed FGF8 at low to moderate intensity. ${ }^{8}$

In view of this discrepancy between our results and those of Leung et al, we proceeded to a further assessment of FGF8 mRNA expression by RT-PCR. All 10 benign hypertrophy specimens and the four tumours showed FGF8 gene expression and this result is consistent with the findings of Ghosh et al. ${ }^{14}$ In our study, the majority of FGF8 expression was by epithelial cells, as evidenced by in situ hybridisation observations. The expression of FGF8 mRNA in tumours was within both malignant and benign elements.

Although there are conflicting views about the levels of androgen receptor expression in well differentiated adenocarcinomatous epithelium as compared with moderately and poorly differentiated carcinomas, ${ }^{30-32}$ our results have shown an inverse correlation between grade and androgen receptor expression in prostate cancer, suggesting that FGF8 loss may be a factor or a marker of genetic change in tumour development. It should be noted that the finding of immunoreactive androgen receptor does not provide conclusive evidence for the presence of a structurally intact, functionally active hormone binding receptor, and mutations in the androgen receptor gene can occur in androgen independent prostate cancer. ${ }^{33-36}$

Our observation of a positive correlation between FGF8 mRNA and androgen receptor expression in prostate cancer suggests that there may be androgen regulation of FGF8 expression and supports previous observations that FGF8 is an androgen dependent growth factor. Sato et al showed that an androgen induced autocrine loop regulated cell growth in the SC-3 mouse mammary cancer cell line. ${ }^{37}$ In their proposed model, stimulation of the SC-3 cells by androgen leads to binding of the activated androgen receptor-androgen complex to the androgen response element of the FGF8 gene, inducing transcription and translation, further binding with a mutated FGFR1 and transformation. However, in contrast to SC-3 cells, the significance of FGF8 in the growth of human prostate cancer is not clearly understood. It is possible that FGF8 could be implicated in a paracrine loop in prostate cancer, confirming the views of Ohuchi et al. ${ }^{38}$

In summary, our study has shown that FGF8 mRNA is expressed in benign prostatic hyper- 
plasia and that there is a positive correlation between expression of FGF8 mRNA and androgen receptor protein in prostate adenocarcinomas, and an inverse correlation with tumour grade. We suggest that there should be an evaluation of androgen receptor and FGF8 expression in relation to clinical prognostic factors in prostate cancer.

1 Cancer Statistics Registrations, 1990 Series MBI No 23. London: Office For National Statistics, 1997.

2 Mortality Statistics: Cause, 1995 Series DH2 No 22. London: Office For National Statistics, 1997.

3 Bower M, Waxman J. Gene therapy for prostate cancer. Semin Cancer Biol 1997;8:3-9.

4 Yamasaki M, Miyake A, Tagashira S, et al. Structure and expression of the rat mRNA encoding a novel member of the fibroblast growth factor family. F Biol Chem 1996;27: 15918-21.

5 Johnson DE, Williams LT Structural and functional diversity in the FGF receptor multigene family. Adv Cancer Res 1993;60:1-41.

6 Basilico C, Moscatelli D. The family of growth factors and oncogenes. Adv Cancer Res 1992;59:115-65.

7 Stamp GWH, Fantl V, Poulsom R, et al. Non-uniform expression of a mouse mammary tumor virus driven int-2 Fgf-3 transgene in pregnancy-responsive breast tumors. Cell Growth Differ 1992;3:929-38.

8 Leung HY, Dickson C, Robson C, et al. Over-expression of fibroblast growth factor 8 in human prostate cancer. Oncogene $1996 ; 12: 1833-5$

9 Tanaka A, Miyamoto K, Minamino N, et al. Cloning and characterization of an androgen-induced growth facto essential for the androgen-dependent growth of mouse mammary carcinoma cells. Proc Natl Acad Sci US 1992;89:8928-32.

10 White RA, Dowler LL, Angeloni SV, et al. Assignment of FGF8 to human chromosome 10q25-q26-mutations in FGF8 may be responsible for some types of acrocephaloFGF8 may be responsible for some types of acrocephalo-

1 Tanaka A, Miyamoto K, Maysuo H, et al. Human androgen-induced growth factor in prostate and breast androgen-induced growth factor in prostate and breast cancer cells: its molecular clon

12 Gemel J, Gorry M, Enruch GD, et al. Structure and sequence of human FGF8. Genomics 1996;35:253-7.

13 Macarthur CA, Shankar DB, Shackleford GM. Fgf-8, activated by proviral insertion, cooperates with the Wnt-1 transgene in murine mammary tumorigenesis. Virology 1995:69:2501-7.

14 Ghosh AK, Shankar DB, Shackleford GM, et al. Molecular cloning and characterization of human FGF8 alternative messenger RNA forms. Cell Growth Differ 1996;7:1425-34.

15 MacArthur CA, Lawshe A, Shankar DB, et al. FGF8 isoforms differ in N1H3T3 cell transforming potential. Cell Growth Differ 1995;6:817-25.

16 Kouhara $\mathrm{H}$, Koga $\mathrm{M}$, Kasayama $\mathrm{S}$, et al. Transforming activity of a newly cloned androgen-induced growth factor. activity of a newly cloned
Oncogene 1994;9:455-62.

17 Yamanaka Y, Friess H, Buciller M, et al. Overexpression of acidic and basic fibroblast growth factors in human pancreatic cancer correlates
Cancer Res 1993;53:5289-96.

18 Kobrin MS, Yamanaka Y, Friess H, et al. Aberrant expression of type 1 fibroblast growth factor receptor in human pancreatic adenocarcinomas. Cancer Res 1993;53: 4741-4.

19 McLeskey SW, Ding IYF, Lippman ME, et al. MDA-MB134 breast carcinoma cells overexpress fibroblast growth factor (FGF) receptors and are growth-inhibited by FGF ligands. Cancer Res 1994;54:523-30.

20 Mansson PE, Adams P, Kan M, et al. Heparin-binding growth factor gene expression and two transplantable rat prostate tumors. Cancer Res 1989;49:2485-94

21 Nakamoto T, Chang C, Li A, et al. Basic fibroblast growth factor in human prostate cancer cell. Cancer Res 1992;52: $571-7$.

22 Mason IJ. The ins and outs of fibroblast growth factors. Cell 1994;78:547-52.

23 Yan G, Pukabori Y, Nikolaropoulos S, et al. Heparinbinding keratinocyte growth factor is a candidate stromal to epithelial cell andromedin. Mol Endocrinol 1992;6:21238.

24 Gleason DF, Mellinger GT, Veterans Administration Cooperative Urological Research Group. Prediction of prognosis for prostatic adenocarcinoma by combined histological grading and clinical staging. F Urol 1974;111:58-64.

25 Poulsom R, Pignatelli M, Stetler-Stevenson WG, et al. Stromal expression of $72 \mathrm{kDa}$ type IV collagenase (MMP-2) and TIMP-2 MRNAs in colorectal neoplasia. Am f Pathol 1992;141:389-96.

26 Melton DA, Rebaliati MR, Maniatis T, et al. Efficient in vitro synthesis of biologically active RNA and RNA hybridisation probes from plasmids containing a bacteriophage SP6 promoter. Nucl Acid Res 1984;12:7035-56.

27 Tokunaga K, Nakamura Y, Sakata K, et al. Enhanced expression of a glyceradehyde-3-phosphate dehydrogenase gene in human lung cancers. Cancer Res 1987;47:5616-19.

$28 \mathrm{Lu}$ QL, Laniado M, Abel PD, et al. Expression of bcl-2 in bladder neoplasms is a cell lineage associated and p53-independent event. Mol Pathol 1997;50:28-33.

29 Poulson P, Hanby AM, Lalani EN, et al. Intestinal trefoil factor (TFF3) and pS2 (TFF1), but not spasmolytic polypeptide (TFF2) mRNAs are co-expressed in normal, hyperplastic, and neoplastic human breast epithelium. $\mathcal{f}$ Pathol 1997;189:30-8.

30 Chodak GW, Kranc DM, Puy LA, et al. Nuclear localization of androgen receptor in the normal, hyperplastic and neoplastic human prostate. F Urol 1992;147:798-803.

31 Van Der Kwast TH, Schalken J, Ruizeveld De Winter JA, et al. Androgen receptor in endocrine-therapy-resistant human prostate cancer. Int $\mathcal{F}$ Cancer 1991;48:189-93.

32 Sadi MV, Walsh PC, Barrack E. Immunohistochemistry study of androgen receptors in metastatic prostate cancer-comparison of receptor content and response to hormonal therapy. Cancer 1991;67:3057-64.

33 Culig Z, Hobisch A, Cronauer MV, et al. Mutant androgen receptor detected in an advanced-stage prostatic carcinoma is activated by adrenal androgens and progesterone. Mol Endocrinol 1993; 7:1541-50.

34 Suzuki H, Sato N, Watabe Y, et al. Androgen receptor gene mutations in human prostate cancer. F Steroid Biochem Mol Biol 1993;46:759-65.

35 De Winter R, Janssen PJA, Sleddens HMEB, et al. Androgen receptor status in localized and locally progresive hormone refractory human prostate cancer. $\mathrm{Am} \mathcal{F}$ Pathol 1994;144:735-46.

36 Taplin ME, Bubley GJ, Shuster TD, et al. Mutation of the androgen-receptor gene in metastatic androgenindependent prostate cancer. N Engl f Med 1995;332: 1393-8.

37 Sato B, Kouhara H, Koga M, et al. Androgen-induced growth factor and its receptor: demonstration of the androgen-induced autocrine loop in mouse mammary carcinoma cells. F Steroid Biochem Mol Biol 1993;47:91-8.

38 Ohuchi $\mathrm{H}$, Yoshioka $\mathrm{H}$, Tanaka $\mathrm{A}$, et al. Involvement of androgen-induced growth factor (Fgf-8) gene in mouse embryogenesis and morphogenesis. Biochem Biophys Res Commun 1994;204:882-8. 